\title{
Repertório sociocultural e gênero dissertativo-argumentativo na redação do ENEM e na dissertação de francês do BAC
}

Daniela Nienkötter Sardá"
Vanessa Fonseca Barbosa**

\section{Resumo}

Ao concluírem a Educação Básica, alunos do Brasil e da França são solicitados a escrever textos do gênero dissertativo-argumentativo no ENEM e no baccalauréat (BAC) respectivamente. O objetivo do artigo é comparar o gênero redação/dissertação escolar tal como ele é praticado nos exames oficiais no Brasil e na França, a fim de melhor compreender as especificidades do trabalho com o gênero dissertativo-argumentativo nas línguas-culturas brasileira e francesa. Para tanto, analisaremos textos oficiais do Ministério da Educação de cada país e trechos de cinco redações nota mil do ENEM e de cinco dissertações autênticas publicadas na França. O trabalho baseia-se na inter-relação entre princípios epistemológicos da abordagem dialógica do discurso (ADD) e na análise de discursos comparativa, de origem francesa e estudada pelos membros do laboratório CLESTHIA-CEDISCOR. No Brasil, o grupo de pesquisa Diálogo (CNPq/ USP) tem buscado aproximar os sabe- res de ambas as vertentes mencionadas, tal como realizado neste estudo.

Palavras-chave: Análise de discursos comparativa; Abordagem dialógica do discurso; ENEM; Baccalauréat.

\section{Introdução}

No Brasil, a aprendizagem da escrita nas aulas de Língua Portuguesa baseia-se na noção de gênero do discurso (cf. BAKHTIN, 2016). Os Parâmetros Curriculares Nacionais (PCNs) de Linguagens, Códigos e suas Tecnologias ${ }^{1}$, publicados pelo Ministério da Educação

\footnotetext{
* Doutora em Ciências da Linguagem pela Université Paris Descartes. Realizou pesquisa de pós-doutorado na Universidade de São Paulo, com financiamento da FAPESP. Membro do grupo Diálogo (CNPq/USP). E-mail: danielasarda@gmail.com

** Pós-doutoranda FFLCH/DLCV/USP (CAPES). Doutora em Letras pela PUCRS (CNPq/CAPES) e Mestra em Linguística pela UCPel (CAPES). Membro dos Grupos de Pesquisas: GenTe - Tessitura: Vozes em (Dis)curso (CNPq/PUCRS); Diálogo (CNPq/USP). Membro Colaborador do GT/ANPOLL: Discurso, Trabalho e Ética. E-mail: vanessafonbar@gmail. com
}

Data de submissão: abr. 2021 - Data de aceite: jul. 2021 http://dx.doi.org/10.5335/rdes.v17i2.12619 
brasileiro entre os anos de 1997 (Ensino Fundamental) e 2000 (Ensino Médio), desenvolveram reflexões essenciais para que os professores pudessem

[...] [t]rabalhar as linguagens não apenas como formas de expressão e comunicação, mas como constituidoras de significados, conhecimentos e valores (BRASIL, 2006, p. 25).

Os documentos oficiais da área de Linguagens, Códigos e Suas Tecnologias destacaram a importância do trabalho docente voltado sobretudo para o ensino, o domínio e a compreensão dos diversos gêneros do discurso que circulam socialmente, considerando esse conceito como um dos princípios para a promoção das competências e habilidades necessárias à formação dos estudantes para a cidadania, ao final do Ensino Médio, isto é, quando da conclusão do processo de ensino-aprendizagem na Educação Básica. Tal como disposto nos PCNs,

[...] [o] estudo dos gêneros discursivos e dos modos como se articulam proporciona uma visão ampla das possibilidades de uso da linguagem, incluindo-se aí o texto literário (BRASIL, 2000b, p. 8).

No ano de 2017 foi promulgada no Brasil a Base Nacional Comum Curricular (BNCC),

[...] um documento de caráter normativo que define o conjunto orgânico e progressivo de aprendizagens essenciais que todos os alunos devem desenvolver ao longo das etapas e modalidades da Educação Básica (BRASIL, 2017, p. 7).
No que diz respeito à área de Linguagens, a BNCC manteve o destaque dado pelos PCNs para a concretização de um trabalho docente por meio de diferentes gêneros discursivos, uma vez que os saberes

[...] sobre os gêneros, sobre os textos, sobre a língua, sobre a norma-padrão, sobre as diferentes linguagens (semioses) devem ser mobilizados em favor do desenvolvimento das capacidades de leitura, produção e tratamento das linguagens (BRASIL, 2017, p. 67).

Tais conhecimentos, segundo prescrito no documento,

[...] devem estar a serviço da ampliação das possibilidades de participação em práticas de diferentes esferas/campos de atividades humanas (BRASIL, 2017, p. 67).

Embora seja muito generalizado no Brasil, o ensino de gêneros não é uma especificidade brasileira. Em países como a França, por exemplo, a aprendizagem da escrita também passa pelo estudo dos gêneros discursivos. Segundo Claudel e Laurens (2016, p. 1), o gênero é um objeto de ensino e aprendizagem na França, particularmente no caso do ensino de francês como língua materna (L1). Mencionamos o caso da França porque o objeto deste artigo é uma análise comparativa de discursos oriundos dessas duas línguas-culturas: a brasileira e a francesa.

A análise de discursos comparativa teve origem na França por volta dos anos 2000 e atualmente é trabalhada 
pelos membros do laboratório CLESTHIA-CEDISCOR (Université Sorbonne Nouvelle - Paris 3 e outras ${ }^{2}$ ). No Brasil, o grupo de pesquisa Diálogo (CNPq/USP) tem buscado aproximar os saberes dessa vertente com a abordagem dialógica do discurso (ADD). Este trabalho seguirá essa mesma metodologia, ancorando-se na inter-relação entre princípios epistemológicos da ADD, com base em trabalhos escritos por Mikhail Bakhtin e outros autores que fizeram parte do Círculo, bem como em pressupostos da análise de discursos comparativa tal qual é praticada na França.

Também é importante observar que o presente estudo resulta de uma colaboração entre duas pesquisadoras: uma cujos trabalhos versam sobre a análise de discursos comparativa, e outra, sobre a compreensão e a análise da linguagem/ língua considerada a partir dos postulados do Círculo de Bakhtin, notadamente os escritos de Mikhail Bakhtin, Valentin Volóchinov e Pavel Medviédev. As reflexões desenvolvidas por esses autores voltam-se, sobretudo, para o caráter social da linguagem, considerando-a na sua íntima relação com a

[...] realidade da enunciação, na qual há a permanente troca de dizeres e a construção de sentidos entre os múltiplos indivíduos que formam a sociedade (BARBOSA, 2017, p. 32).

Nessa perspectiva, o conceito de gêneros discursivos, por exemplo, ganha destaque nos trabalhos dos pensadores russos, uma vez que explica a produção e a circulação de enunciados (orais e escritos) em diferentes esferas da sociedade, com os mais variados fins comunicativos, pois

[...] [a] riqueza e a diversidade dos gêneros do discurso são infinitas porque são inesgotáveis as possibilidades da multifacetada atividade humana (BAKHTIN, 2016, p. 12).

Selecionamos para esta reflexão um corpus relativo ao gênero dissertativo-argumentativo. Interessa-nos, em particular, examinar os processos envolvidos no ensino, na aprendizagem e, principalmente, nos critérios de avaliação da escrita daquele gênero por alunos que concluem a Educação Básica com vistas à preparação para os exames nacionais nestes dois contextos: o Exame Nacional do Ensino Médio (ENEM), no Brasil, e o exame baccalauréat ${ }^{3}$ (ou BAC), na França.

Em ambos os países se espera do aluno, ao final da sua escolaridade, que ele domine a escrita do gênero dissertativo-argumentativo. Na França, fala-se simplesmente de dissertação, mas, conforme esclarece Denizot (2013, p. 2), “[n] os textos oficiais dos anos 2000-2010, a dissertação é claramente ligada à argumentação"4. No contexto francês, a dissertação está presente em mais de uma das disciplinas que compõem o exame do baccalauréat ${ }^{5}$; ao contrário do Brasil, em que a escrita desse gênero é solicitada no processo seletivo do ENEM apenas na prova de redação, junto às questões 
objetivas da área de Linguagens, Códigos e suas Tecnologias. No caso da França, neste trabalho, nosso interesse volta-se somente para a dissertação da prova escrita do BAC de francês. Todavia, é importante ressaltar que o aluno francês pode escolher entre três propostas de escrita na prova de língua francesa: escrita inventiva, comentário de texto ou dissertação literária ${ }^{6}$.

No contexto brasileiro, dentre as cinco competências estipuladas pelos critérios de correção e avaliação do texto dissertativo-argumentativo, escolhemos para a análise duas delas, por acreditarmos que são as que nos permitem melhor observar o modo como a competência argumentativa dos estudantes é avaliada nos textos do corpus brasileiro, especialmente no que diz respeito ao seu repertório sociocultural e ao desenvolvimento da autoria. Trata-se das competências 2 e 3 , respectivamente: "Compreender a proposta de redação e aplicar conceitos das várias áreas de conhecimento para desenvolver o tema, dentro dos limites estruturais do texto dissertativo-argumentativo em prosa" e "Selecionar, relacionar, organizar e interpretar informações, fatos, opiniões e argumentos em defesa de um ponto de vista" (BRASIL, 2020, p. 8). Já nos textos oficiais franceses é dito que a dissertação "consiste em realizar uma reflexão pessoal e argumentada a partir de uma problemática literária oriunda do programa de francês. Para desenvolver a sua argumentação, o candidato basear-se-á em textos de que ele dispõe, nos "'objetos de estudo" do segundo ano do Ensino Médio, assim como nas suas leituras e na sua cultura pessoal"'. (FRANCE, 2006). Donde a importância da aprendizagem desse gênero do discurso para a formação de um cidadão apto a lidar com os desafios do mundo contemporâneo, que exige cada vez mais a formação de um sujeito crítico capaz de aprender a aprender. Numa sociedade voltada para a multiplicidade dos saberes, a escrita do gênero dissertativo-argumentativo torna-se primordial.

Pensamos, pois, que a análise do ensino e aprendizagem da argumentação, em ambas as culturas, é um ponto relevante para a comparação discursiva. Decidimos analisar as indicações presentes nos textos oficiais do Ministério da Educação de cada país (PCNs, BNCC, cartilha do ENEM e os seus equivalentes franceses) relativos ao uso de um repertório sociocultural por parte dos estudantes na realização desses exames. Também farão parte do nosso corpus trechos de cinco exemplos de redação nota mil do ENEM (extraídas das cartilhas do participante do ano de 2020), bem como cinco dissertações autênticas publicadas na França, no livro Les meilleures copies $d u$ Bac (2015). Tanto as cartilhas quanto o referido livro apresentam comentários 
acerca da avaliação dada (justificando as notas obtidas pelos participantes).

$\mathrm{O}$ artigo será dividido da seguinte forma: primeiramente, apresentaremos a análise de discursos comparativa de inspiração bakhtiniana para, em seguida, apresentarmos o processo de compreensão dos enunciados na ADD. Feito isso, mostraremos como a argumentação é trabalhada no ensino brasileiro e francês. As demais seções concernem aos critérios de seleção do corpus, análises propriamente ditas, conclusão e referências.

\section{Uma análise de discursos comparativa de inspiração bakhtiniana}

Conforme anunciamos na introdução, a análise de discursos comparativa teve origem na França por volta dos anos 2000 , e no momento atual é trabalhada notadamente pelos membros do laboratório CLESTHIA-CEDISCOR (Université Sorbonne Nouvelle - Paris 3 e outras). No Brasil, o grupo de pesquisa Diálogo (CNPq/USP) tem buscado aproximar os saberes dessa vertente com aqueles de uma análise de discursos de inspiração bakhtiniana (análise dialógica do discurso).

Numa análise do tipo comparativa não comparamos somente línguas, mas também culturas. Além disso, é por meio do gênero do discurso que essa análise é levada a cabo, pois é o gênero que serve como tertium comparationis, ou seja, como a invariante que garante a comparação. Nas palavras de Grillo (2020, p. 26),

[...] [o] objetivo central da análise comparativa de enunciados de duas línguas/culturas [...] é levar-nos à identificação das especificidades de ambas decorrentes do contraste.

Por isso, interessa-nos, neste artigo, comparar o gênero redação/dissertação escolar tal como ele é praticado nos exames oficiais no Brasil e na França, a fim de melhor compreender as especificidades do trabalho com o gênero dissertativo-argumentativo em cada língua-cultura.

Em outras publicações (cf. SARDÁ, 2021 ; 2020) apresentamos um panorama bastante completo dessa abordagem. Privilegiaremos, aqui, o diálogo com a ADD e o conceito de compreensão, que nos servirá como uma categoria nocional para a análise do nosso corpus.

\section{Alguns dos princípios gerais da ADD e o processo de compreensão dos enunciados}

Aos nos debruçarmos sobre os escritos oficiais respeitantes à Educação Básica brasileira, percebemos, além de citações ${ }^{8}$ dos autores do Círculo de Bakhtin, muitas outras passagens em que conceitos-chave desses pensadores ${ }^{9}$ figuram. É, portanto, evidente a contribuição, 
no Brasil, dos estudos bakhtinianos na orientação dada aos professores para a adoção de uma perspectiva enunciativo-discursiva norteadora do trabalho com a linguagem. Citemos dois exemplos dessas passagens: um que se encontra na introdução do material dedicado ao ensino de Língua Portuguesa, e outro atinente a um dos conceitos e competências gerais a serem desenvolvidos com os alunos nas aulas de redação, denominados Interlocução, significação, dialogismo:

1) Cabe à escola aprimorar a competência gramatical dos alunos, de modo a levá-los a gerar seq[u]ências próprias, consideradas como admissíveis e aceitáveis no interior da Língua Portuguesa, bem como compreender enunciados distintos (BRASIL, 2000b, p. 57 - grifos nossos).

2) Conceitos envolvidos na produção de enunciados pertinentes à situação de uso, tanto na fala quanto na escrita. As diversas trocas sociais possibilitam que os falantes de uma língua produzam enunciados, de acordo com certas intenções, dentro de determinadas condições, o que origina efeitos de sentido. Quando se dialoga com alguém ou se lê um texto, é pela interlocução que se constroem os sentidos; também é nela que os interlocutores se constituem e são constituídos. Tais conceitos perpassam quase todas as atividades da disciplina. Compete, porém, ao professor de Língua Portuguesa propor situações que incentivem a produção de textos orais e escritos nas quais se considerem: um público ouvinte ou um leitor específico; a situação de produção em que se encontram os interlocutores; as intencionalidades dos produtores. O que se propõe é que as aulas de redação operem com esses conceitos, para que a atividade adquira significado para o aluno (BRASIL, 2000 b, p. 61 - grifos nossos).
Ao elegerem o enunciado como unidade básica e real de análise, os autores do Círculo colocam no centro da poética sociológica o estudo dos múltiplos acentos axiológicos e, por conseguinte, dos sentidos que se estabelecem na e pela linguagem. Tal estudo, segundo eles, é capaz de oferecer uma abordagem adequada "sobre as particularidades específicas do material, das formas e dos propósitos de cada campo da criação ideológica" (MEDVIÉDEV, 2012, p. 44). Isso, é claro, não desconsidera a importância de todos os níveis de análise linguística (fonológico, morfológico, sintático e semântico) apontados pelos estudos precedentes, mas os incorpora e os considera no desenvolvimento de um trabalho metalinguístico, o qual pressupõe que toda oração, palavra e informação formulada na linguagem

[...] dirige-se a alguém, é suscitada por alguma coisa, tem algum objetivo, ou seja, é um elo real na cadeia da comunicação discursiva em determinado campo da atividade humana ou da vida (BAKHTIN, 2016, p. 46).

$\mathrm{Na}$ abordagem da ADD, portanto, os enunciados elaborados pelos sujeitos não são construções que podem ser tidas como puramente objetivas, neutras e alheias ao universo de valores e signos ideológicos que os constituem. Tais enunciados exprimem inúmeras vozes e ideologias sociais que podem ser colocadas em tensão discursiva, representando diferentes, e até mesmo divergentes, pontos de vista sobre o mundo. Assim, 
[...] cada gênero é capaz de dominar somente determinados aspectos da realidade, ele possui certos princípios de seleção, determinadas formas de visão e compreensão dessa realidade (MEDVIÉDEV, 2012, p. 44).

Em consequência, ao partirmos desses postulados para observar e analisar a linguagem, debruçamo-nos sobre os discursos sociais constituídos, com vistas a melhor compreendê-los por meio de "uma concepção de linguagem e de discurso como elementos constitutivos e indissociáveis dos sujeitos e das suas historicidades" (BARBOSA, 2017, p. 21). Nesse sentido, compreendemos também que todo ato de linguagem, além de ser um elo da cadeia discursiva, apresenta posicionamentos distintos sobre o universo de valores em que se (trans)forma; a própria "compreensão da realidade desenvolve-se e origina-se no processo da comunicação social ideológica" (MEDVIÉDEV, 2012, p. 44).

Podemos, então, dizer que quando um sujeito elabora um texto, a exemplo dos estudantes brasileiros que analisaremos neste trabalho, espera-se que ele não só seja capaz de dominar os elementos formais característicos do gênero dissertativo-argumentativo, mas também de articular e organizar adequadamente a sua compreensão sobre dado tema proposto pela prova de redação. Conforme destaca Volóchinov (2018, p. 178) "de modo algum o processo de compreensão deve ser confundido com o processo de reconhe- cimento [...]. Apenas um signo pode ser compreendido, já o sinal é reconhecido"; ou seja, o que importa ao falante é que o conhecimento das formas linguísticas, sobre o qual refletiu bastante no processo da sua educação básica, seja suficiente para lhe permitir, na composição dos seus textos (orais e escritos), organizar, veicular, defender, analisar e articular o seu modo de compreensão de fenômenos mundanos. Não esqueçamos de que, sob essa óptica, os textos produzidos pelos estudantes fazem parte da cadeia dialógica dos discursos já ditos e daqueles que serão proferidos, uma vez que

[...] o discurso verbal impresso participa de uma espécie de discussão ideológica em grande escala: responde, refuta ou confirma algo, antecipa as respostas e críticas possíveis, busca apoio e assim por diante (VOLÓCHINOV, 2018, p. 219) .

Ao nos debruçarmos sobre os textos dos alunos brasileiros e franceses, com base nos postulados da ADD, observamos até que ponto os autores das redações se posicionam ativamente no processo de comunicação dialógica e demonstram compreender a proposta de escrita que lhes é solicitada no processo seletivo. Em outras palavras, examinaremos de que maneira brasileiros e franceses constroem os seus argumentos a partir de uma compreensão, a qual consideraremos como um processo ativo, capaz de revelar modos peculiares e subjetivos de interpretar e valorar o mundo. 
Na concepção dos autores do Círculo, "a interpretação e a resposta estão dialeticamente fundidas e se condicionam mutuamente: uma é impossível sem a outra" (BAKHTIN, 2015, p. 55). Do mesmo modo que a compreensão - "no sentido exato dessa palavra, isto é, a sua orientação em um dado contexto e em dada situação" (VOLÓCHINOV, 2018, p. 179) - pressupõe que o sujeito seja capaz de interpretar dada realidade, ela reflete e refrata a percepção, os valores e as vozes sociais deste, os quais constituem a sua maneira de compreender as palavras enquanto signos ideológicos.

\section{O ensino brasileiro nos documentos oficiais e a argumentação como competência necessária}

Embora saibamos que os Parâmetros Curriculares Nacionais (PCNs) não tivessem um objetivo normativo quando da sua formulação, isto é, não propusessem regras que devessem necessariamente ser seguidas pelos professores da Educação Básica, é inegável o papel dos PCNs na reorganização geral dos critérios de avaliação, construção e estruturação dos modos de ensino e aprendizagem. A primeira grande contribuição trazida pelo documento foi, a nosso ver, alertar para a necessidade de transfor- mar a compreensão do modo como deve se estruturada a aprendizagem em sala de aula no Brasil.

O ensino - que até então se dava de modo "descontextualizado, compartimentalizado e baseado no acúmulo de informações" (BRASIL, 2000a, p. 4) provenientes das diversas disciplinas que compunham os currículos escolares - passou a ser apresentado e defendido, nos documentos oficiais, por meio do agrupamento de conteúdos e questões de três grandes áreas do saber: Linguagens, Códigos e suas Tecnologias; Ciências da Natureza, Matemática e suas Tecnologias; e Ciências Humanas e suas Tecnologias. Com isso, buscou-se

[...] dar significado ao conhecimento escolar, mediante a contextualização; evitar a compartimentalização, mediante a interdisciplinaridade; e incentivar o raciocínio e a capacidade de aprender (BRASIL, 2000a, p. 4).

Outra contribuição significativa resultante do trabalho com os PCNs foi a ênfase na promoção de atividades escolares fundadas no desenvolvimento de competências e habilidades. O objetivo daquelas é capacitar os alunos, ao final da educação básica, para a ação situada, "tanto para o exercício da cidadania quanto para o desempenho de atividades profissionais. A garantia de que todos desenvolvam e ampliem suas capacidades é indispensável para se combater a dualização da sociedade" (BRASIL, 2000a, p. 11) e, consequente- 
mente, para evitar o crescimento das desigualdades sociais, conforme observa o documento.

A BNCC, apesar de ter suas especificidades e também algumas modificações em relação ao documento anterior, não minimizou a ênfase dos PCNs numa escolarização voltada para desenvolvimento de competências que tornam os sujeitos capazes de agir adequadamente nos cinco principais campos de atuação social: o campo da vida cotidiana (Anos iniciais) e pessoal (Anos finais e Ensino Médio); o campo artístico-literário; o campo das práticas de estudo e pesquisa; o campo jornalístico-midiático e o campo de atuação na vida pública (BRASIL, 2017). Ao serem devidamente trabalhadas e aprimoradas durante a educação básica, as competências estipuladas, segundo os autores do documento, possibilitam aos estudantes se servir de

[...] conhecimentos (conceitos e procedimentos), habilidades (práticas, cognitivas e socioemocionais), atitudes e valores para resolver demandas complexas da vida cotidiana, do pleno exercício da cidadania e do mundo do trabalho (BRASIL, 2017, p. 8).

Essa importância dada, tanto nos PCNs quanto na BNCC, ao saber interdisciplinar e contínuo reflete-se sobretudo na defesa de uma postura enunciativo-discursiva num trabalho com a linguagem que não se circunscreva apenas ao ensino de Língua Portuguesa, mas que se estenda a todas as áreas que compõem a formação curricular da educação básica brasileira. No que diz respeito ao desenvolvimento da capacidade de argumentar e aos seus desdobramentos (elaboração, análise, síntese, apresentação etc. de argumentos e contra-argumentos), encontramos inúmeros destaques no documento, em todas as áreas do ensino, que sinalizam a relevância da argumentação como requisito indispensável para a formação de um sujeito crítico e reflexivo. Como exemplos dessas passagens, fizemos a seguir quatro recortes, na parte que trata do Ensino Médio, referentes às seguintes áreas da BNCC: Linguagem, Códigos e suas Tecnologias; Matemática e suas Tecnologias; Ciências da Natureza e suas Tecnologias; e Ciências Humanas e suas Tecnologias:

1) Analisar, em textos argumentativos, os posicionamentos assumidos, os movimentos argumentativos (sustentação, refutação/ contra-argumentação e negociação) e os argumentos utilizados para sustentá-los, para avaliar sua força e eficácia, e posicionar-se criticamente diante da questão discutida e/ ou dos argumentos utilizados, recorrendo aos mecanismos linguísticos necessários (BRASIL, 2017, p. 507 - grifos nossos).

2) Com relação à competência de argumentar, seu desenvolvimento pressupõe também a formulação e a testagem de conjecturas, com a apresentação de justificativas [...] em relação às competências de raciocinar e representar (BRASIL, 2017, p. 530 - grifos nossos). 
3) Analisar e debater situações controversas sobre a aplicação de conhecimentos da área de Ciências da Natureza [...], com base em argumentos consistentes, legais, éticos e responsáveis, distinguindo diferentes pontos de vista (BRASIL, 2017, p. 559 - grifos nossos)

4) Elaborar hipóteses, selecionar evidências e compor argumentos relativos a processos políticos, econômicos, sociais, ambientais, culturais e epistemológicos, com base na sistematização de dados e informações de diversas naturezas (expressões artísticas, textos filosóficos e sociológicos, documentos históricos e geográficos, gráficos, mapas, tabelas, tradições orais, entre outros) (BRASIL, 2017, p. 572 - grifos nossos).

Vemos, portanto, que o trabalho com a argumentação na BNCC pressupõe - para além da compreensão e identificação do conceito em textos dos mais diversos gêneros (orais e/ou escritos), bem como a sua circulação nas múltiplas esferas sociais - que os estudantes devem apropriar-se do conhecimento para que sejam capazes de agir correta e conscientemente no mundo. Ações estas que podem resultar, com base em argumentos, em raciocínios críticos e posicionamentos coerentes, que estejam de acordo com a Lei e com princípios morais.

Assim, a maior avaliação oficial do país e a que melhor possibilita verificar a capacidade argumentativa dos estudantes está, em nosso entendimento, na prova de redação do $\mathrm{ENEM}^{10}$, precisamente nos dois critérios de seleção da avaliação que recortamos para a análise desenvolvida neste artigo:
Figura 1 - Competências 2 e 3 de avaliação na redação do ENEM

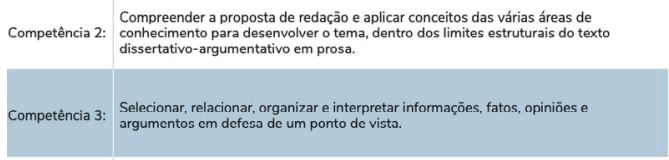

Fonte: (BRASIL, 2020, p. 8).

Ao explicar o que será pressuposto na avaliação da segunda competência, na matriz de referência disponível na Cartinha do Participante do ENEM, encontramos o seguinte destaque para a argumentação enquanto requisito ao desenvolvimento do tema de acordo com o gênero solicitado (dissertativo-argumentativo):

É mais do que uma simples exposição de ideias; [...] você deve assumir claramente um ponto de vista [...]. Trata-se, portanto, de uma competência que avalia as habilidades integradas de leitura e de escrita (BRASIL, 2020, p. 15).

Outro aspecto deveras importante dessa competência relaciona-se à presença de um repertório sociocultural no texto dos estudantes, o qual "se configura como uma informação, um fato, uma citação ou uma experiência vivida que, de alguma forma, contribui como argumento para a discussão proposta" (BRASIL, 2020, p. 16). Ainda com relação à segunda competência avaliada, os autores da Cartilha oferecem algumas recomendações para a obtenção da nota máxima, dentre as quais destacamos a seguinte: 
Utilize informações de várias áreas do conhecimento, demonstrando que você está atualizado em relação ao que acontece no mundo. Essas informações devem ser pertinentes ao tema e usadas de modo produtivo no seu texto, evidenciando que elas servem a um propósito muito bem definido: ajudá-lo a validar seu ponto de vista. Isso significa que essas informações devem estar articuladas à discussão desenvolvida em sua redação. Informações e citações soltas no texto, por mais variadas e interessantes que sejam, perdem sua relevância quando não associadas produtivamente à defesa do ponto de vista desenvolvido em seu texto (BRASIL, 2020, p. 16).

Embora todas as competências avaliadas no processo de escrita da redação do ENEM estejam inter-relacionadas, observamos que a terceira competência está mais intimamente vinculada com a segunda, uma vez que elas se complementam. Pois a fim de que as etapas de seleção, organização e interpretação de fatos, opiniões e argumentos se desenvolvam, os estudantes terão de compreender primeiro o que lhes é solicitado sobre o tema da prova e, só depois, serem capazes de encadear os argumentos para a constituição da sua função autoral mediante a redação. É por meio desses passos que conseguirão defender um ponto de vista, compreendendo a constituição dos argumentos como: "as justificativas para convencer o leitor a concordar com seu ponto de vista" (BRASIL, 2020, p. 30).

\section{A argumentação como competência necessária no ensino da dissertação literária do BAC de francês}

O lugar que a dissertação ocupa na vida de um estudante de lycée (Ensino Médio), na França, dependerá de alguns fatores. Primeiramente, é importante observar que o ensino francês é dividido em "vias" de formação e de diplomas, bem como em "séries". As vias são divididas, atualmente, em "via geral" (voie générale) e "via tecnológica" (voie technologique). Além disso, existe a opção de cursar um Ensino Médio profissional (lycée professionnel). No interior dessas vias - da via geral, por exemplo - há divisões em "séries". Aqui, a passagem do ano 2020 para o ano de 2021 traz algumas mudanças. Ou seja, esse processo está em transformação neste exato momento. Assim, de acordo com a página do Ministério da Educação francês:

A via geral está em transformação:

Para os alunos de terceiro ano [terminale] de 2020 ela compreende ainda três séries (ES [econômica e social], L [literária] e S [científica]) que levam ao baccalauréat geral.

Para os alunos que passam o baccalauréat geral em 2021 as séries deram lugar a especialidades, escolhidas ao final do segundo ano [do Ensino Médio].

A via geral conduz à continuação dos estudos no Ensino Superior, principalmente na universidade, classes preparatórias e grandes écoles ou em escolas especializadas ${ }^{11}$. (FRANCE, 2021) 
Não entraremos, aqui, em detalhes sobre toda a organização do Ensino Médio francês, mas é fácil perceber que, se a via geral conduz aos estudos universitários, o peso da dissertação, na prova do baccalauréat - exame que marca a conclusão da Educação Básica na França, também chamado de BAC -, será maior. Além disso, para um aluno da série literária as disciplinas de ciências humanas têm um coeficiente mais elevado e, assim, a prova escrita de francês do BAC terá, também, uma maior importância, fazendo com que ele estude os diversos gêneros nela envolvidos (comentário, dissertação e escrita inventiva), ao passo que um aluno do Ensino Médio profissionalizante não dará tanta atenção ao gênero dissertação, considerado o mais difícil entre as três possibilidades. Não é por acaso que o interesse pela escrita da dissertação, na França, parece diminuir a cada ano. De acordo com uma matéria publicada no jornal Le Figaro ainda em 2014, os candidatos do BAC, mesmo os da série literária, não querem mais dissertar ("Les candidats au bac ne veulent plus disserter"12): "São entre $10 \mathrm{e}$ $15 \%$ os que escolhem a dissertação, preferindo o comentário e a "escrita inventiva" $(B E Y E R, 2014)^{13}$. A reforma atualmente em curso tem por objetivo eliminar a opção da escrita inventiva como forma de solucionar esse problema.

Os textos oficiais do Ministério da Educação francês dão uma grande ênfase ao desenvolvimento da argumentação, já antes da reforma em curso. Por isso que, na definição do termo "dissertação", apresentada mais acima neste artigo, afirma-se que esta envolve "uma reflexão pessoal e argumentada a partir de uma problemática literária oriunda do programa de francês"14 (FRANCE, 2006 [grifo nosso]). É o que confirma Denizot (2013), no seu artigo intitulado "La dissertation: un genre scolaire argumentatif ?":

Nos textos oficiais dos anos 2000-2010, a dissertação está claramente associada à argumentação, como o mostra a definição atual da prova EAF (Prova antecipada de francês; BO especial no 7 de 6 de outubro de 2011), que continua estritamente idêntica desde 2001 [...] [aqui, temos o mesmo excerto comentado por nós logo acima] Essa definição evoca numerosas passagens dos programas: os "liceanos" "devem ser capazes, a partir de suas leituras, de formular um julgamento pessoal argumentado, notadamente num comentário ou numa dissertação"; "os exercícios de análise, de comentário e de dissertação concorrem" ao "domínio da expressão escrita autônoma" nos "escritos de argumentação e de deliberação" (programa de segundo ano do liceu, BO no 28 de 12 de julho de 2001); e, no programa de primeiro ano como no de segundo ano, comentário e dissertação são os dois únicos exercícios citados na rubrica da "escrita argumentativa") (BO especial 9 de 30 de setembro de 2010) ${ }^{15}$. (DENIZOT, 2013, p. 165)

Ou seja, a dissertação é tida nos programas franceses, segundo Denizot (2013), por um "gênero argumentativo". Todavia, da mesma forma que, no Brasil, a redação do ENEM, tida por um texto de tipo $^{16}$ dissertativo-argumentativo, acabou por se tornar um gênero próprio - o 
gênero "redação do ENEM" (cf. Lima \& Bacelar, 2019; Oliveira, 2016, à guisa de exemplo) -, a dissertação literária, como a da prova do BAC de francês que analisaremos neste artigo, acaba tornando-se um gênero à parte:

De certa maneira, a dissertação literária resiste a ser descrita simplesmente como um gênero argumentativo, e reduzi-la ao seu componente argumentativo, longe de ser uma ajuda à sua produção, é, sem dúvida, um obstáculo tanto metodológico quanto cognitivo, tanto mais ela continua sendo um gênero avaliativo, cuja dimensão temática (a dos conteúdos) é central ${ }^{17}$. (DENIZOT, 2013, p. 173)

A questão levantada acima, bem como os argumentos levantados por Denizot (2013), retornarão nas nossas análises. Além da questão do conteúdo temático, vemos, também, que na França um outro aspecto bastante valorizado no ensino do gênero dissertação é a sua construção composicional. Isso porque, "no domínio do FL1 [francês língua materna], os gêneros foram abordados no quadro das pesquisas sobre o interacionismo sociodiscursivo (Bronckart et al. 1985, Bronckart 1996) [...]"18 (CLAUDEL \& LAURENS, 2016, p. 2). Na tradição brasileira de ensino de Língua Portuguesa há um maior ecletismo em matéria de abordagem, graças, também, à crescente expansão de pesquisas em Linguística e Linguística Aplicada, cujo principal objetivo é o desenvolvimento de metodologias e materiais didáticos com vistas a potencializar o ensino de línguas no país. Dispostos esses aspectos, veremos nas análises qual a relação entre o repertório sociocultural e a cultura pessoal dos alunos nos exames oficiais, e o seu vínculo com a argumentação.

\section{A seleção do corpus}

O corpus da pesquisa é constituído por textos oficiais do Ministério da Educação brasileiro e francês, bem como de excertos de cinco redações/dissertações autênticas, produzidas por estudantes brasileiros e franceses.

Quanto aos textos oficiais, temos no Brasil, atualmente, a Base Nacional Comum Curricular como documento normativo de maior referência para a organização da Educação Básica. Contudo, conforme destacamos, a sua elaboração não desconsiderou o trabalho precedente realizado pelos PCNs, por isso optamos por apresentá-los neste artigo, demonstrando a sua importância no desenvolvimento e na continuidade das reflexões sobre a Educação Básica, tal como são apresentadas pela BNCC. Além desses documentos, recorremos também à Cartilha do Participante do ENEM do ano de 2020. Nesta, temos não apenas o Manual com as normas de constituição e avaliação da prova de redação, mas também exemplos de textos que gabaritaram o último processo seletivo realizado do ENEM e que nos indicam o que os avaliadores esperam encontrar nos textos dos candidatos 
relativamente ao desenvolvimento das duas competências que analisaremos. Ademais, a inclusão desse material na nossa análise se deveu, também, ao fato de que, ao tratarmos do modo de seleção e ingresso dos estudantes nas Instituições de Ensino Superior (IES) públicas e privadas do país, a prova do ENEM é a mais aceita para o preenchimento de vagas nas universidades. $\mathrm{E}$, no caso da prova de redação, ela é a única que não é composta de questões objetivas, ou seja, aquela que nos permite observar, na escrita, a maneira como se encadeiam os argumentos dispostos textualmente.

Já para o contexto francês selecionamos as informações contidas no site do Ministério da Educação da França sobre o lycée (Ensino Médio), bem como o texto de lei retirado do Diário Oficial do país sobre a prova escrita de francês do baccalauréat (FRANCE, 2021; 2006). Além disso, consultamos o programa de ensino de francês do segundo ano das séries gerais e tecnológicas conforme divulgado no diário oficial de 2001 (FRANCE, 2001) e nas suas versões especiais $\mathrm{n}^{\circ} 9$, de 30 de setembro de 2010 (FRANCE, 2010), e nº 3 , de 17 de março de 2011 (FRANCE, 2011).

No que concerne às redações/dissertações propriamente ditas, para a língua-cultura brasileira analisamos cinco excertos de redações nota mil presentes na cartilha do INEP de 2020 (BRASIL, 2020) e os comentários dos avaliadores da prova que se referem explicitamente às competências 2 e 3 , com foco no repertório sociocultural dos estudantes. A prova de redação do ENEM 2019 (a qual contém a amostra dos textos disponível na Cartilha de 2020) teve o seguinte tema: "Democratização do acesso ao cinema no Brasil". O material por nós consultado disponibiliza, ao total, sete redações que obtiveram nota máxima e os respectivos comentários dos avaliadores acerca das competências desenvolvidas pelos estudantes. Para a nossa investigação, no entanto, selecionamos as cinco primeiras amostras disponibilizadas na Cartilha a fim de que pudéssemos ter o mesmo número de textos que foram selecionados em francês. Dessa forma, chegamos às produções textuais dos seguintes estudantes brasileiros: Gabriel Melo Caldas Nogueira; Maria Antônia de Lima Barra; Stela Terra Lopes; Gabriel Merli; e Gustavo Lopes Teixeira.

Para a língua-cultura francesa a seleção do material revelou-se mais difícil, pois o governo do país não disponibiliza nem mesmo as dissertações com notas mais elevadas (na França, a escala avaliativa é de 0 a 20). Conseguimos solucionar esse impasse consultando cinco textos do livro Les meilleures copies $d u$ $B A C$ ("As melhores provas do BAC"), publicado em 2015 pela professora Coralie Nuttens. Os textos desse livro são autênticos; produzidos por seus alunos, e por ela corrigidos e comentados. Selecionamos aqueles cujas notas vão de 15 a 18 . 
Argumentação e repertório sociocultural nas redações do ENEM e posicionamentos dos avaliadores

Nos cinco excertos aqui analisados podemos dizer que a prova de redação do ENEM é consoante não só às competências que propõe avaliar, mas também aos princípios norteadores da BNCC referentes ao desenvolvimento da argumentação disposta nos textos dos estudantes, já que, pela delimitação do tema para a escrita do texto,

[...] os alunos se deparam com uma variedade de situações que envolvem conceitos e fazeres científicos, desenvolvendo observações, análises, argumentações e potencializando descobertas (BRASIL, 2017, p. 58).

Assim, quando o autor do trecho (1), por exemplo, afirma que "o cinema dialoga com uma elementar necessidade social" e, para ratificar esse argumento, entrelaça-o com a citação de um renomado historiador holandês (Johan Huizinga), ele demonstra, para além do domínio do gênero solicitado, a capacidade de trazer o seu elemento expressivo ao enunciado (BAKHTIN, 2016, p. 57) e, mediante a materialidade linguística, logra inter-relacionar informações precedentes, saberes científicos e a sua formação literária na defesa de determinado ponto de vista:
(1)

Autor: Texto de Gabriel Melo Caldas Nogueira:

1) "Para o filósofo escocês David Hume, a principal característica que difere o ser humano dos outros animais é o poder de seu pensamento, habilidade que o permite ver aquilo que nunca foi visto e ouvir aquilo que nunca foi ouvido. Sob essa ótica, vêese que o cinema representa a capacidade de transpor para a tela as ideias e os pensamentos presentes no intelecto das pessoas".

2) "Em primeiro lugar, é válido frisar que o cinema dialoga com uma elementar necessidade social e, consequentemente, não pode ser deixada em segundo plano. Para entender essa lógica, pode-se mencionar o renomado historiador holandês Johan Huizinga, o qual, no livro 'Homo Ludens', ratifica a constante busca humana pelo prazer lúdico [...]".

3) "[...] é oportuno comentar que o cenário do cinema supracitado remete ao que defende o arcabouço jurídico do país. Isso porque o artigo 215 da Constituição Federal é claro em caracterizar os bens culturais como um direito de todos [...]"

Comentário do avaliador: "Há, também, repertório sociocultural utilizado de maneira produtiva e pertinente à discussão no primeiro parágrafo, com a referência ao que é postulado pelo filósofo David Hume para relacionar o poder de pensamento do ser humano a sua capacidade de transpor ideias por meio do cinema, por exemplo. No segundo parágrafo, o participante aborda o potencial lúdico do cinema, mencionando a obra de Johan Huizinga. Por fim, no terceiro parágrafo, ele se vale da Constituição Federal para afirmar que todos têm direito aos bens artísticos, o que não ocorre na prática, de acordo com pesquisas do IPHAN". 
Trata-se, portanto, de levar os estudantes para além de um saber exclusivamente formal do gênero dissertativo-argumentativo, uma vez que o trabalho com o enunciado concreto, tal como postulado pelos autores do Círculo, permite-nos melhor compreendê-lo enquanto unidade real da comunicação discursiva, assim como "compreender de modo mais correto também a natureza das unidades da língua" (BAKHTIN, 2016, p. 22).

$\mathrm{Na}$ BNCC temos a afirmação de que a compreensão é uma das habilidades essenciais para o ampliar a dimensão do conhecimento dos estudantes, tomando-a em íntima relação com o repertório sociocultural adquirido pelos alunos. Tal como o postula o documento, a compreensão "está também associada ao conhecimento conceitual, [e] refere-se ao esclarecimento do processo de inserção das práticas corporais no contexto sociocultural, reunindo saberes que possibilitam compreender o lugar das práticas corporais no mundo" (BRASIL, 2017, p. 221). Ao analisarmos o exemplo disponível no trecho 2, percebemos que a autora da redação serve-se de parte do seu repertório sociocultural - a partir da menção de um filme (Bastardos Inglórios), da citação de conceitos científicos (como urbanização e gentrificação) e referência a um filósofo e uma escritora respectivamente (Pierre Bourdieu e Carolina de Jesus) - visando mostrar para os avaliadores da prova que ela compreende os enunciados, tanto na cadeia discursiva a que pertencem, isto é, na esfera científica a que pertencem, quanto na defesa do seu posicionamento argumentativo e autoral enquanto prática social:

Autora: Maria Antônia de Lima Barra:

1) "O filme 'Bastardos inglórios', ao contextualizar cenas em meados do século $X X$, retrata o caráter elitista das exibições de cinema, uma vez que eram feitas em espaços de socialização das classes ricas da época".

2) "[...] é fundamental ressaltar que a $\boldsymbol{u r}$ banização tardia e a constante gentrificação de espaços citadinos brasileiros são responsáveis pela permanência de costumes elitistas. Com efeito, o geógrafo Milton Santos, ao estudar a organização das cidades do Brasil, postula que o processo rápido e desorganizado de construção urbana provocou a marginalização de grande parte dos cidadãos".

3) "[...] a teoria do sociólogo Pierre Bourdieu acerca do 'capital cultural' vai ao encontro da realidade discutida. Em seus postulados, Bourdieu discute a influência das referências socioespaciais nos costumes do indivíduo [...]".

4) "Um exemplo disso eé o relato da autora Carolina Maria de Jesus, em seu livro 'Quarto de despejo', no qual ela conta que, por residir na periferia, o dinheiro que seus filhos gastariam para assistir aos longas no cinema naão seria suficiente nem para pagar seus deslocamentos".

Comentário do avaliador: "Observa-se que a participante usa, de forma produtiva, repertório sociocultural pertinente à discussão tanto no primeiro parágrafo (ao comparar o acesso ao cinema no século XX, ilustrado pelo filme 'Bastardos In- 
glórios', aos dias de hoje) quanto ao longo de sua argumentação, em que apresenta e relaciona à questão discutida os conceitos de 'gentrificação', 'marginalização' (geógrafo Milton Santos) e de 'capital cultural' (sociólogo Pierre Bourdieu), além de ilustrar a dificuldade que os moradores da periferia têm de se deslocar até os cinemas, com um episódio do livro 'Quarto de despejo', da escritora Carolina Maria de Jesus”.

Tais observações nos permitem ainda aproximar a avaliação do trabalho com a linguagem no ENEM com a compreensão de que, mais do que um simples e objetivo agrupamento linguístico, quando fazemos uso das palavras, elas estão carregadas "de conteúdo e significação ideológica ou cotidiana” (VOLÓCHINOV, 2018, p. 181).

Nas palavras de Bakhtin (2016, p. 57):

[...] [t]odo enunciado deve ser visto antes de tudo como uma resposta aos enunciados precedentes de um determinado campo [...], ela os rejeita, confirma, completa, baseia-se neles, subentende-os como conhecidos, de certo modo os leva em conta.

Ao analisarmos o trecho 3 , notamos que a autora da redação faz uso de argumentos de autoridade oriundos de discursos precedentes para desenvolver uma relação de contraposição entre eles, ou seja, ela é capaz de "analisar e discutir situações-problema que emerg[e]m de diferentes contextos socioculturais, além de compreender e interpretar leis, teorias e modelos" (BRASIL, 2017, p. 548):
(3)

Autora: Stela Terra Lopes:

1) "A questão do acesso ao cinema, apesar de não ser amplamente discutida, é um problema muito expressivo no Brasil atualmente. Agravidade do quadro é evidenciada pelos dados do site Meio e Mensagem: 83\% da população brasileira não frequentam tal ambiente".

2) "Tendo em vista que a parcela mais pobre da população, geralmente, não consegue arcar com os custos de frequentar o cinema e sabendo que o acesso ao lazer é um direito garantido pela Constituição Federal, percebe-se a ocorrência da 'Cidadania de papel', termo cunhado pelo escritor paulista Gilberto Dimenstein, que diz respeito à existência de direitos na teoria (Constituição), os quais não ocorrem, de fato, na prática. Sob essa perspectiva, nota-se que a falta de democratização do acesso ao cinema gera exclusão social das camadas menos favorecidas e impede que elas possam usufruir de seus direitos.".

Comentário do avaliador: "O tema é abordado de forma completa: já no primeiro parágrafo, a participante aponta que o acesso ao cinema não é democratizado no país, uma vez que grande parcela da população não frequenta o local. Observa-se também que a participante usa, de forma produtiva, repertório sociocultural pertinente à discussão quando faz referência ao conceito de 'Cidadania de papel', proposto por Gilberto Dimenstein, para discutir o fato de que algumas pessoas não têm, na prática, acesso a alguns direitos garantidos pela Constituição".

Desse modo, a autora do texto relaciona um direito garantido pela Constituição brasileira (o direito de todo cidadão ao lazer) com a reflexão de um jornalista e escritor (Gilberto Dimenstein), conseguindo, assim, fazer uma crítica ao país e demonstrando que o texto constitucional 
não condiz com a realidade da sociedade brasileira; o qual se dá apenas no papel, mas não na vida concreta da maioria da população.

Ao vermos o recorte disponível no trecho 4, notamos que o autor da redação também encadeia "os argumentos utilizados para sustentá-los, para avaliar sua força e eficácia, e posicionar-se criticamente diante da questão discutida e/ou dos argumentos utilizados, recorrendo aos mecanismos linguísticos necessários" (BRASIL, 2017, p. 507):

\author{
(4)
}

Autor: Gabriel Merli:

1) "Na obra 'A Invenção de Hugo Cabret', é narrada a relação entre um dos pais do cinema, Georges Mélies, e um menino órfão, Hugo Cabret. A ficção, inspirada na realidade do começo do século $X X$, tem como um de seus pontos centrais o lazer proporcionado pelo cinema, que encanta o garoto. No contexto brasileiro atual, o acesso a essa forma de arte não é democratizado, o que prejudica a disponibilidade de formas de lazer à população.”.

2) "Primeiramente, o direito ao lazer está assegurado na Constituição de 1988, mas o cinema, como meio de garantir isso, não tem penetração em todo território brasileiro".

3) "Ademais, o problema existe também em locais onde há salas de cinema, uma vez que o custo das sessões é inacessível às classes de renda baixa. Isso se deve ao fato de o mercado ser dominado por poucas empresas exibidoras. Conforme teorizou inicialmente o pensador inglês Adam Smith, o preço decorre da concorrência: a competitividade força a redução dos preços, enquanto os oligopólios favorecem seu aumento. Nesse sentido, a baixa concorrência dificulta o amplo acesso ao cinema no Brasil”.
Comentário do avaliador: "O tema é abordado de forma completa, revelando uma leitura cuidadosa da proposta de redação: ainda no primeiro parágrafo, o participante anuncia a problemática ao abordar a centralização das salas de cinema e o preço elevado dos ingressos que impedem a democratização efetiva do cinema. Observa-se também o uso produtivo de repertório sociocultural pertinente à discussão proposta pelo participante em mais de um momento do texto: no primeiro parágrafo, o filme 'A Invenção de Hugo Cabret' foi utilizado com o objetivo de contextualizar o tema, apresentando o cinema como um lugar de lazer; no segundo parágrafo, o participante compara o que é assegurado pela Constituição Federal com a situação atual do pais; $e$, no terceiro parágrafo, ele se vale de um argumento de autoridade, encontrado no pensamento de Adam Smith, para fundamentar a justificativa de que o preço dos ingressos é alto porque há poucas empresas atuando no Brasil.".

Isso demonstra que o autor é capaz de pôr em movimento as palavras, considerando

[...] a língua ideologicamente preenchida, a língua enquanto cosmovisão e até como uma opinião concreta que assegura um maximum de compreensão mútua em todos os campos da vida ideológica (BAKHTIN, 2015, p. 40).

Para tanto, esse autor relaciona o conhecimento que detém, proveniente de diversas áreas do saber, para a defesa da sua compreensão da problemática estabelecida na prova escrita (A democratização do acesso ao cinema no Brasil).

No trecho 5 o autor desenvolve os seus argumentos notadamente a partir da relação entre o sistema capitalista 
e a sua consequente busca pelo lucro, vinculando-a com a impossibilidade de popularizar a frequentação ao cinema no Brasil:

Autor: Gustavo Lopes Teixeira:

1) "No século XIX, os avanços tecnológicos e científicos proporcionaram às populações novas alternativas de lazer, dentre as quais se pode citar o cinema. No Brasil, atualmente, tal forma de diversão tem se destacado, uma vez que promove a interação com o público de maneira singular, isto é, gera muitas emoções aos indivíduos. Apesar disso, verifica-se que, em nosso país, o acesso a cinema não é disponibilizado a todos os cidadão, seja pela falta de investimentos, seja pelo alto custo cobrado por empresas para assistir a um filme".

2) "Sob esse viés, pode-se apontar as poucas verbas direcionadas à construção e à manutenção de cinemas, especialmente nas pequenas cidades brasileiras, como uma das causas do problema em questão. Acerca disso, sabe-se que boa parte da população que vive em áreas rurais ou suburbanas sofre com a falta de acessibilidade a tal meio de diversão. Prova dessa realidade é o filme 'Cine Hollyúde', lançado no Brasil, o qual mostra a dificuldade das pessoas que habitam no interior em assistir à primeira obra cinematográfica da cidade, devido à precariedade estrutural do cinema local. Tal cenário também é observado fora da ficção, visto que, por causa dos poucos investimentos, indivíduos das regiões pobres do país possuem mínima ou nenhuma interação com essa forma de lazer".

3) "Ademais, nota-se, ainda, uma intensa elitização dos cinemas, porquanto o preço cobrado pelo ingresso de uma sessão é alto, o que limita a ida a esses lugares de exibição de filmes. Sobre isso, percebe-se que, como a busca por tal lazer aumentou, de acordo com dados do 'site' 'Meio e mensagem', as empresas exibidoras estão cada vez mais visando ao lucro em detrimento de uma diversão e interação pública. Isso ocorre, segundo o pensador Karl Marx, graças à busca excessiva por capital (dinheiro), tornando o cinema apenas como um 'lugar lucrativo'. Desse modo, a democratização do acesso a esses locais torna-se distante da realidade vivida”.

Comentário do avaliador: "[...] Além disso, o tema é abordado de forma completa, o que revela uma leitura cuidadosa da proposta de redação: o participante apresenta o problema em discussão já no primeiro parágrafo, enfatizando sua importância como alternativa de lazer. Observa-se também o uso produtivo de repertório sociocultural pertinente à discussão proposta em mais de um momento do texto: no segundo parágrafo, há a referência ao filme 'Cine Holliúdy', o qual tem a função de exemplificar a ausência de salas de cinema no interior do país; no terceiro parágrafo, o participante apresenta um argumento de autoridade, na figura de Karl Marx, para explicar os altos valores dos ingressos para o cinema".

A compreensão marxista do tema, feita por meio do repertório sociocultural do estudante, pode também ser aproximada da compreensão de linguagem segundo Volóchinov (2018, p. 107-108), quando o autor menciona que

[...] [t]odas as formas de interação discursiva estão estreitamente ligadas às condições de dada situação social concreta, e reagem com extrema sensibilidade a todas as oscilações do meio social.

O pensador russo coloca no centro da poética sociológica a discussão sobre os problemas de filosofia da linguagem 
para o marxismo no seu conjunto (VOLÓCHINOV, 2018, p. 85). Quanto ao estudante, este faz uso do seu repertório sociocultural para desenvolver o

[...] seu modo próprio de raciocinar, representar, comunicar, argumentar e, com base em discussões e validações conjuntas, aprender conceitos e desenvolver representações e procedimentos cada vez mais sofisticados (BRASIL, 2017, p. 529).

Pela análise dos excertos dos textos escritos pelos estudantes brasileiros, podemos, pois, afirmar que, grosso modo, eles atingem satisfatoriamente os objetivos da prova de redação, seguindo os princípios basilares de trabalho, compreensão e mobilização da linguagem na estrutura dos seus argumentos. Tal postura é

[...] fundamental para que os estudantes possam entender, avaliar, comunicar e divulgar o conhecimento científico, além de lhes permitir uma maior autonomia em discussões (BRASIL, 2017, p. 552).

Um último aspecto que nos chamou a atenção, no caso das atividades brasileiras, diz respeito ao modo bastante rígido e sedimentado numa mesma sequência textual dos discursos dos avaliadores da prova de redação do ENEM. Em todos os exemplos recortados encontramos as seguintes afirmações: "o tema é abordado de forma completa" e há "o uso produtivo de repertório sociocultural pertinente à discussão proposta em mais de um momento do texto". Talvez a necessidade desse texto mais padronizado se deva ao grande número de redações que cada ava- liador precisa corrigir num curto período de tempo. Pois, no Brasil, os corretores são selecionados cada ano, recebendo em função da quantidade de textos corrigidos, conforme disposto no edital de seleção. Ademais, o fato de sempre contar com um tema bastante amplo pode dificultar comentários personalizados dos avaliadores nos textos de cada estudante. $\mathrm{Na}$ seção a seguir observaremos como isso ocorre no caso do BAC.

\section{Leituras e cultura pessoal na dissertação do BAC: entre argumentação e demonstração de aprendizagem de conteúdos escolares}

Haja vista que o presente artigo é voltado para o público brasileiro, mantivemos, no título, o termo "repertório sociocultural", tal como ele é empregado nos textos oficiais no Brasil. Nesse contexto, o repertório sociocultural

[...] se configura como uma informação, um fato, uma citação ou uma experiência vivida que, de alguma forma, contribui como argumento para a discussão proposta (BRASIL, 2020, p. 16).

Os textos oficiais franceses apresentam outros termos. Na definição de dissertação apresentada pelo Ministério da Educação francês são empregados os termos ou expressões "textos que ele [o 
aluno] dispõe", "objetos de estudo", "leituras" e "cultura pessoal":

Para desenvolver sua argumentação, o candidato apoiar-se-á em textos que ele dispõe, nos "objetos de estudo" do segundo ano do Ensino Médio assim como em suas leituras e em sua cultura pessoal (FRANCE, 2006).

Os termos acima apresentados, presentes no contexto francês, recobrem a realidade de uma prova cujo conteúdo é mais específico do que o da prova brasileira: trata-se, na França, de uma dissertação literária. Nesse sentido, pensamos que os termos "textos que ele [o aluno] dispõe" (que aparecerá no enunciado das provas aqui analisadas como "corpus") e "objetos de estudo" referem-se exclusivamente aos conteúdos trabalhados em sala de aula durante o segundo ano do Ensino Médio francês, e que são objeto de verificação de aprendizagem na França. Já os termos "leituras" e "cultura pessoal" corresponderiam ao nosso "repertório sociocultural".

O programa de ensino de francês (FRANCE, 2001) apresenta os seguintes "objetos de estudo", no interior da seção "conteúdos", para as classes de todas as séries do ensino geral e tecnológico:

1 - Movimento literário e cultural [...]

2 - A poesia [...]

3 - O teatro: texto e representação [...]

4 - Convencer, persuadir e deliberar: as formas e as funções do ensaio, do diálogo e do apólogo [...]

5 - O biográfico [... $]^{19}$ (FRANCE, 2001)
Nesse documento não constam títulos de obras a serem trabalhadas. No item 1 , sobre os movimentos literários e culturais, é dito que "[n]o segundo ano, estuda-se enquanto tal um movimento literário e cultural francês e europeu do século XVI ao XVIII; outros movimentos o são em relação a outros objetos de estudo. Constrói-se as relações de comparação e de cronologia entre os movimentos estudados no primeiro e no segundo ano"20 (FRANCE, 2001). Vê-se, portanto, que os objetos de estudo podem ser a poesia, o teatro, etc. Todavia, a lista de autores e de obras muda cada ano ${ }^{21}$, ou seja, os candidatos devem estar atentos a essa publicação antes de prestar o exame.

Vejamos como se distribuem as referências aos autores num enunciado do nosso corpus. Lembramos ainda que os excertos abaixo foram retirados do livro Les meilleures copies du BAC e foram corrigidas pela professora que 0 organizou. A fim de traçar um paralelo com a análise das redações do ENEM, analisaremos os trechos cujas marcas de correção, na margem do texto, apresentam a sigla "B" (de bien) e "TB" (de très bien).

O excerto (1) abaixo responde ao seguinte enunciado:

Você acha que a poesia nos afasta da realidade ou, ao contrário, nos ajuda a percebê-la melhor? Você responderá a essa pergunta com um desenvolvimento argumentativo, embasado nos textos do corpus, naqueles que você estudou em sala de aula, bem 
como nas suas leituras pessoais. Corpus: Victor Hugo, J'aime l'araignée, Les Contemplations, 1856.; Charles Baudelaire, Les Fenêtres, Le Spleen de Paris, 1869; Francis Ponge, Le Pain, Le Parti pris des choses, $1942^{22}$.

(1) [...] Le poète est aussi attentif aux choses anodines qui l'environnent comme T. Gauthier qui dans « Farniente " aime à observer la fourmis, le puceron, la chenille, la limace ou le papillon. Le poète est aussi celui qui « montre rues, sous une lumière qui secoue la torpeur, les choses surprenantes qui nous environnent " comme le dit Cocteau dans Le Rappel à l'ordre ${ }^{23}$. En effet la poésie ravive les lieux communs, nous fait voir ce que nous ne voyions plus par une simple coup de baguette magique. Cette magie passe par le jeu sur le rythme, les rimes ou les images ainsi les trous du haillon du mendiant deviennent une constellation chez Hugo et la Terre est « bleue comme une orange " chez Eluard $/{ }^{24}$ C'est donc bien le rôle du poète que de nous aider à percevoir le réel grâce à l'acuité de sa vue et sa maîtrise du langage. [...] (Corpus francês, p. 17) [Nota 16/20.].

[[...] O poeta está também atento às coisas insignificantes que o cercam como T. Gauthier que em "Farniente" formiga, o pulgão, a lagarta, a lesma ou a borboleta. $O$ poeta é também aquele que "mostra ruas, sob uma luz que sacode o torpor, as coisas surpreendentes que nos cercam" como diz Cocteau em Le rappel à l'ordre. Com efeito a poesia reaviva os lugares-comuns, nos faz ver o que não víamos mais por um simples toque de varinha de condão. Essa magia passa pelo jogo com o ritmo, as rimas ou as imagens assim os furos no farrapo do mendigo tornam-se uma constelação em Hugo e a Terra é "azul como uma laranja” em Eluard / É portanto o papel do poeta nos ajudar a perceber a realidade graças à sua acuidade visual e fluência linguística. [...]]
Vemos nesse excerto que o objeto de estudo é a poesia, proposta ao estudante a partir da questão motivadora, provocando-lhe a assumir a sua "ativa posição responsiva na comunicação" (BAKHTIN, 2016, p. 44). Para tanto, e a fim de sustentar a sua argumentação, o aluno mobilizou, nesse excerto, um dos autores presentes no corpus: no caso, Victor Hugo. Além disso, ele traz novas referências, citadas tanto em discurso direto quanto indireto: temos a obra "Farniente", de Gauthier, "Le rappel à l'ordre", de Cocteau, e uma menção a um trecho da obra de Éluard. Essas obras e citações servem como argumentos para que o aluno responda à questão principal "Você acha que a poesia nos afasta da realidade ou, ao contrário, nos ajuda a percebê-la melhor?". Em outras palavras, por meio de argumentos literários o aluno demonstra ter compreendido o enunciado da questão e se insere no (in)tenso processo dialógico de sentidos instaurados na e pela linguagem.

Vejamos esse outro excerto, em resposta a uma questão cujo objeto de estudo também é a poesia:

(2) [...] Enfin, il semble que la beauté d'un poème n'est pas obligatoirement liée à une souffrance, physique, morale, ou spirituelle. Tout d'abord parce que une grande partie des sentiments humains peut tout à fait servir à l'inspiration poétique. Y compris ceux diamétralement opposé[s] à la souffrance, comme Aragon ${ }^{26}$ dans son recueil Le Phenix, célèbre Dominique, sa muse, qui renouvelle sa poésie dans la joie, le bon- 
heur et le plaisir. D'autres sujets servent également à créer une superbe poésie, sans que le poète souffre, comme les poèmes de Marcel Pagnol qui célèbrent la faune et la flore des paysages qu'il décrit avec amour dans ses romans, " [L]e pillon " par exemple. Ensuite car mêler des sentiments divergents voire contraires est aussi un moyen de créer la beauté en poésie. Et cela à l'échelle du poème même, comme avec «M[a]tinée d'Ivresse » de Rimbaud où le [ilegível] et le plaisir se ve[u]lent dans une « [f] anfare atroce" sur un " chevalet féerique ». Ou bien à l'échelle du recueil de poème[s], comme avec les Fleurs du Mal de Baudelaire. La multitude de sentiments qui travaillent le poète confère une beauté à chacun.[...] (Corpus francês, p. 29) [Nota 16/20]

[Enfim, parece que a beleza de um poema não está obrigatoriamente relacionada ao sofrimento, físico, moral ou espiritual. Antes de tudo porque uma grande parte dos sentimentos humanos pode servir de inspiração poética. Inclusive aqueles diametralmente oposto[s] ao sofrimento, como Aragon na sua coletânea Le Phenix, celebra Dominique, a sua musa, que renova a sua poesia na alegria, na felicidade e no prazer. Outros temas também servem para criar uma poesia soberba, sem que o poeta sofra, como os poemas de Marcel Pagnol que celebram a fauna e a flora das paisagens que ele descreve com amor nos seus romances, "Le pillon" por exemplo. Em segundo lugar porque misturar sentimentos divergentes ou mesmo contrários é também uma maneira de criar beleza na poesia. $\mathrm{E}$ isso no âmbito do próprio poema, como no "Matinée d'Ivresse" de Rimbaud em que o [ilegível] e o prazer se pretendem numa "[f] anfarra atroz" sobre um "cavalete feérico". Ou então no âmbito da coletânea de poema[s], como com les Fleurs du Mal, de Baudelaire. A multidão de sentimentos que trabalham o poeta confere uma beleza a cada um deles. [...] ].
O excerto acima responde ao seguinte enunciado:

Os mais desesperados são os mais belos cantos, / E conheço alguns imortais que são puros prantos, escreve Alfred Musset na sua Nuit de mai. Comente e discuta essa afirmação baseando-se nos textos do corpus e nos poemas que você conhece. Corpus: Alfred de Musset, La Nuit de mai, Les Nuits, 1835; Théophile Gautier, Le Pin des Landes, Espagna, 1845; Victor Hugo, Demain dès l'aube, Les Contemplations, 1856; Paul Éluard, Notre Vie, Le Temps déborde, $1947^{27}$.

Vemos aqui, pela correção da professora - a sinalização na margem do texto que destaca o fato de que, no lugar de "Aragon", o aluno deveria ter escrito "Éluard" -, que no contexto francês importa averiguar a veracidade das citações apresentadas, o que também demonstra que "a literatura ocupa um lugar importante nesse meio ideológico" (MEDVIÉDEV, 2012, p. 198) de formação do estudante francês. Assim, mais do que somente inserir, por exemplo, dada citação de filósofo e teórico situado numa área específica do pensamento, os avaliadores têm formação e conhecimento suficientes para averiguar se dada informação está correta. Não significa, é claro, que esses avaliadores são melhores do que os seus homólogos brasileiros; trata-se, sim, de considerar o fato de que o exame francês não é corrigido em grande escala como o brasileiro, e que não se exige dos avaliadores o conhecimento específico na área do saber correspondente a cada utilização 
do repertório sociocultural mobilizado pelo estudante na escrita da redação. De resto, na França, as bancas são montadas com professores que corrigem as provas diretamente na versão em papel. E no caso do excerto (2) que estamos analisando, podemos notar que, mesmo esse exemplo estando incorreto (isto é, a autoria da citação não correspondendo à apontada pelo estudante), isso não invalida o restante da análise da sua escrita, a qual está muito bem fundamentada com exemplos convergindo para um ponto de vista autoral, em que ele defende que "a beleza de um poema não está obrigatoriamente relacionada ao sofrimento, físico, moral ou espiritual". A defesa desse ponto de vista atesta que o estudante compreendeu o enunciado da questão, na qual a relação da poesia com o tema do sofrimento é apresentada em forma de versos, com um trecho da obra de Alfred Musset. Numa perspectiva dialógica de análise da linguagem, podemos ainda dizer que "[e]sse discurso é debatido em um diálogo direto e vivo e, além disso, é orientado para uma percepção ativa: uma análise minuciosa [...] bem como uma reação organizada" (VOLÓCHINOV, 2018 , p. 219). No caso em foco, voltado para o discurso-resposta da avaliadora.

Vejamos o excerto (3):

(3) [...] Enfin, le poète dévoile les choses grâce au travail sur le rythme et les sonorités. Ainsi Delerme nous fait entendre par les allitérations en « $\mathrm{f}$ » et « $\mathrm{r}$ » le «petit frrfrr » de la dynamo : " ce petit frottement qui freine et frotte en ronronnant contre la roue ». Certes le langage sert à dévoiler les objets qui nous environnent et que nous ne voyons plus, mais la poésie a aussi d'autres fonctions. [...] (Corpus francês, p. 54) [Note $15 / 20$ ]

[...] Enfim, o poeta revela as coisas graças ao trabalho com o ritmo e as sonoridades. Assim Delerme nos faz escutar pelas aliterações em "f" e "r" o "pequeno frrfrr" do dínamo: "aquela fricçãozinha que freia e esfrega enquanto ele ronrona contra a roda". Decerto a linguagem serve para revelar os objetos que nos cercam e que nós não vemos mais, embora a poesia também tenha outras funções. [...]

Esse excerto é uma resposta à seguinte questão:

Jean Cocteau define assim o papel da poesia: Ela revela, no sentido mais forte do termo. Ela mostra nuas, sob uma luz que sacode o torpor, as coisas surpreendentes que nos cercam e que os nossos sentidos registravam maquinalmente. Em que medida você compartilha dessa concepção de poesia? Você responderá a essa pergunta num desenvolvimento argumentativo, embasado nos textos do corpus, naqueles que você estudou em sala de aula, bem como nas suas leituras pessoais. Corpus: Jean Cocteau, Le Secret professionnel, 1926 ; Francis Ponge, Le Parti pris des choses, 1942, Jacques Réda, Retour au calme, $1989 .{ }^{28}$

Aqui temos, pela primeira vez, uma menção a uma obra da literatura mais recente: de Philippe Delerm, poeta nascido em 1950. O estudante utiliza-se, na sua argumentação, de um trecho memorizado que faz parte das suas leituras, logo da sua "cultura pessoal", o que também denota a vivacidade e riqueza das palavras, lidas através do prisma 
dos estudos dialógicos, uma vez que "a língua, para a consciência que nela vive [...] é uma opinião concreta e heterodiscursiva sobre o mundo" (BAKHTIN, 2015 , p. 69). O trecho transcrito acima é assinalado pela professora com a sigla "TB" (très bien); inferimos, portanto, que a banca de professores franceses costuma valorizar esse tipo de exemplo.

No trecho (4) temos o exemplo de um repertório que não é originário da esfera literária:

4) $[. .$.$] Le point de vue du romancier peut$ être exprimé dans son œuvre mais [le] lecteur n'est pas obligé de le partager. De plus, il ne faut pas réduire un roman à son contenu idéologique car il ne serait alors plus qu'un essai. Ainsi, il ne faut pas réduire le cycle des Rougon-Macquart de Zola à son contenu d'idées car il serait alors comparable aux travaux d'Auguste Comte. De même, si l'on ne prend que le contenu scientifique de Thérèse Raquin de Zola, ce serait réduire l'œuvre aux travaux de Claude Bernard sur l'hérédité. Un roman est donc, avant d'être un contenu idéologique, un contenant littéraire qui n'est clairement pas un prétexte à la création des personnages. [...] (Corpus francês, p. 98) [Note 17/20]

[[...] O ponto de vista do romancista pode ser expresso na sua obra, mas [o] leitor não é obrigado a compartilhá-lo. Além disso, não se deve reduzir um romance ao seu conteúdo ideológico, pois então não seria mais do que um ensaio. Assim, não se deve reduzir o ciclo Les Rougon-Macquart de Zola ao seu conteúdo de ideias, pois ele seria então comparável aos trabalhos de Auguste Comte. Da mesma forma, se tomarmos apenas o conteúdo científico de Thérèse Raquin de Zola, isso seria reduzir a obra aos trabalhos de Claude Bernard sobre a hereditariedade. Um romance é, portanto, antes de ser um conteúdo ideológico, um continente literário que claramente não é um pretexto para a criação de personagens. [...]]

Trata-se do excerto de uma dissertação que respondeu ao seguinte enunciado:

No seu entendimento, em que medida a expressão das ideias tem espaço no gênero romance? Você responderá a essa pergunta num desenvolvimento ordenado que se baseará nos textos do corpus, naqueles que você estudou em sala de aula, bem como nas suas leituras pessoais. Corpus: Victor Hugo, L'Homme qui rit, 1869; Jules Vallès, Le Bachelier, 1881; Émile Zola, Germinal, $1885 .^{29}$

É interessante notar, nesse caso, que a interdisciplinaridade aqui apresentada, com a menção aos trabalhos de Auguste Comte e Claude Bernard, serve como base para a defesa de um ponto de vista sobre a literatura: o de que "não se deve reduzir um romance ao seu conteúdo ideológico" e que “[u]m romance é, portanto, antes de ser um conteúdo ideológico, um continente literário" e, ao ser assim considerado, podemos aproximá-lo do modo de compreensão do enunciado na ótica dos autores do Círculo, para os quais: "a tarefa de compreensão não se reduz ao reconhecimento da forma usada, mas à sua compreensão em um contexto concreto, à compreensão de sua significação em um enunciado" (VOLÓCHINOV, 2018, p. 177). Novamente, no trecho (4), temos um trecho que sinaliza 
a compreensão do enunciado da prova por parte do estudante, que lança mão de argumentos transliterários a fim de defender um ponto de vista. Lembramos, ainda, que a interdisciplinaridade é um dos pontos a serem trabalhados no programa de francês:

\section{$\mathrm{V}$ - RELAÇÕES COM AS OUTRAS DISCI- PLINAS}

Disciplina transversal, o francês desenvolve as competências indispensáveis para todas as disciplinas.

Relações mais precisas serão estabelecidas e indicadas como tais aos alunos com as seguintes disciplinas:

- as artes, notadamente para o estudo dos gêneros e registros, história cultural e análise de imagens;

- as línguas antigas, para o estudo dos gêneros e registros, história literária e cultural, e léxico;

- as línguas vivas, particularmente na abordagem dos movimentos culturais europeus;

- a história, incluindo a história das ciências, para a construção de problemáticas da história cultural;

- a filosofia, que os alunos abordarão no terceiro ano do Ensino Médio, através de reflexão sobre registros, história cultural e idioma, e através de capacitação para comentários de textos, bem como a dissertação. Essa lista não é exaustiva; cada professor a enriquecerá de acordo com o projeto pedagógico da classe e da escola. ${ }^{30}$ (FRANCE, 2001)

Uma questão como a que foi colocada anteriormente no excerto, sobre a "expressão das ideias", tem por objetivo verificar se o aluno assimilou não só os conteúdos do programa de francês do segundo ano do Ensino Médio, como também o de outras disciplinas, de modo que seja capaz de estabelecer relações entre os conteúdos aprendidos durante a sua escolaridade.

Por fim, no excerto (5) também temos a menção a uma obra da contemporaneidade, quando o aluno cita o teatro-dança de Pina Baush:

(5) [...] À l'instar des costumes, des accessoires et du décor, le rythme constitue également un moyen favorisant l'interprétation d'une œuvre théâtrale. Le rythme conditionne une pi[è]ce. En le modifiant, le metteur en scène $d[$ [é]truit un monde pour en reconduire un. Il d[é]fait l'un des [é]l[é]ments de la colonne vertébrale de l'œuvre afin d'en créer une nouvelle davantage en phase avec sa vision de la pièce. Par exemple, dans le théâtre-danse de Pina Baush, l'absence de texte conduit à réo[r]chestrer un rythme caract[é]ristique du théâtre. Elle transmet une vision du monde non plus par la parole mais par le corps. Par ailleurs, en insistant sur le registre tragique. Eric Vignier dans la mise en scène de l'Ecole des Femmes modifie le rythme et crée ainsi une nouvelle interprétation de l'œuvre originale. Au final, divers él[é]ments et moyens participent à faire de la mise en scène d'une œuvre théâtrale, une interprétation à sa manière. Cependant, interpr[é]ter l'œuvre d'un dramaturge pourrait être à ses yeux d'auteur assimilable [à] une trahison. (Corpus francês, p. 124-125) [Note 18/20]

[[...] A exemplo de figurinos, adereços e cenários, o ritmo é também um meio que favorece a interpretação de uma obra teatral. $\mathrm{O}$ ritmo condiciona uma $\mathrm{p}[\mathrm{e}]$ ça de teatro. Ao modificá-lo, o diretor destrói um mundo para produzir um novo. Ele d[e]sfaz um dos [e]l[e]mentos da espinha dorsal da obra a fim de criar uma nova que esteja mais em sintonia com a sua visão da peça. Por exemplo, no teatro-dança de Pina Baush, 
a ausência de texto leva a reo[r]questrar um ritmo caracter[í]stico do teatro. Ele transmite uma visão do mundo não mais pela palavra, mas pelo corpo. Além disso, ao insistir no registro trágico, Eric Vignier na sua encenação de L'École des Femmes muda o ritmo e cria assim uma nova interpretação da obra original. No final, diversos el[e]mentos e meios contribuem para tornar a encenação de uma obra teatral, uma interpretação à sua maneira. No entanto, interpretar a obra de um dramaturgo poderia ser aos seus olhos de autor assimilado [a] uma traição.]

O excerto acima responde à seguinte questão do exame:

Em que medida a encenação de uma obra teatral constitui uma interpretação desta? Você responderá a essa pergunta num desenvolvimento argumentativo embasado nos textos do corpus, nas peças de teatro que você estudou em sala de aula, bem como nas suas leituras pessoais. Corpus: Molière, Les Précieuses ridicules, 1659; Molière, L'École des femmes, 1662, Beaumarchais, Le Mariage de Figaro, $1782 .^{31}$

Nesse exemplo, a professora também assinalou, nas margens da dissertação, a sigla "TB" (très bien). Feitas as análises, cremos que temos, aqui, um exemplo das virtudes de um estudo comparativo: a distinção entre os termos "repertório sociocultural", "objetos de estudo", "leituras" e "cultura pessoal", por um lado, e a observação da sua aplicação no textos analisados, por outro, nos fez compreender que, na França, a adoção do gênero dissertativo-argumentativo como objeto de ensino e de avaliação é voltado para dois objetivos distintos: 1) é por meio desse gênero que os alunos franceses aprenderão a argumentar e 2) é o próprio gênero que servirá de baliza para a verificação, por parte dos professores-avaliadores do exame do BAC, da aprendizagem dos conteúdos de literatura francesa pelos alunos. Dias-Chiaruttini (2014) esclarece, no seu artigo, que a noção de gênero é, entre outras funções, uma "ferramenta de análise, tanto teórica quanto metodológica, da evolução dos conteúdos disciplinares e das práticas educativas" ${ }^{32}$ (p. 9), mas que essa abordagem tem os seus limites. Denizot (2013) assinala que o gênero dissertação literária escolar não era tão argumentativo quanto afirmado nos programas, e que se tratava muito mais de um gênero para "medir" a apropriação de conteúdos.

Nossas análises confirmaram em partes essas observações, pois, mesmo que os estudantes se valham dos exemplos para mostrar que conhecem os autores e os conteúdos, os textos bem avaliados costumam, sim, prezar por uma boa argumentação, com os exemplos convergindo para a defesa de um ponto de vista coerente.

\section{Conclusão}

Neste estudo, por meio da análise de documentos e avaliações oficiais que circulam no Brasil e na França, buscamos comparar de que modo essas duas culturas trabalham com textos do gênero 
redação/dissertação escolar. Assim, procuramos compreender melhor as especificidades do trabalho com a escrita de textos dissertativo-argumentativos nas línguas-culturas brasileira e francesa. Auxiliaram as nossas reflexões os escritos dos autores do Círculo de Bakhtin e da análise de discursos comparativa, tal como desenvolvida pelos membros do laboratório CLESTHIA-CEDISCOR. Isso nos permitiu encontrar alguns pontos de convergência entre o trabalho realizado com a redação/dissertação nos dois contextos investigados, assim como delinear as especificidades de cada um.

No que diz respeito aos principais pontos de convergência entre o Brasil e a França, mencionamos os seguintes: em ambos os países os estudantes são estimulados ao desenvolvimento de argumentos dispostos de modo claro e objetivo, com vistas a demonstrarem que têm boa compreensão e formação literária, as quais se refletem na elaboração dos seus escritos. Nesse ponto, o repertório sociocultural dos estudantes das duas culturas é também fundamental, pois se trata de um conhecimento que lhes permite defender determinados posicionamentos autorais na elaboração dos seus textos. Vimos também que os estudantes brasileiros e franceses são expostos, na sua formação básica, a um trabalho com os gêneros discursivos/textuais que lhes possibilita compreender a linguagem para além do conhecimento exclusivamente estrutural/ formal, ainda que este também lhes seja essencial para o trabalho discursivo. Nas duas culturas-alvo também foi possível observar os enunciados produzidos pelos estudantes em estreita relação com a intensa e complexa cadeia dialógica de discursos, considerando, é claro, as especificidades das situações discursivas em que cada um deles se insere.

Quanto aos aspectos específicos de cada cultura, pudemos perceber que a Literatura ocupa um espaço de maior prestígio e privilégio no contexto francês do que no brasileiro, haja vista que os estudantes europeus têm a sua avaliação dirigida pela leitura de algumas obras literárias e precisam recorrer, ademais, a outros conhecimentos provenientes da sua formação pessoal na escrita do texto. No que concerne aos textos dos avaliadores das provas de redação, notamos que, na França, a banca parece ter mais liberdade com relação aos pareceres elaborados, já que eles são individuais e menos atrelados a critérios específicos, se comparados aos brasileiros, que são intimamente relacionados às competências e habilidades dispostas nos critérios de avaliação da redação do ENEM. 


\section{Sociocultural repertoire and argumentative-dissertative genre in ENEM's composition and BAC's dissertation}

\section{Abstract}

At the end of secondary education, students from Brazil and France are asked to compose texts of dissertativeargumentative genre in ENEM and baccalauréat (BAC) respectively. The aim of this article is to compare the genre school composition/dissertation as it is practiced in official exams in Brazil and France, in order to better understand the specificities of the work with dissertative-argumentative genre in the Brazilian and French languages-cultures. To this end, we shall analyse official texts from the Ministry of Education in each country and excerpts from five compositions gotten top mark in ENEM, and five authentic dissertations published in France. The work is based on the interrelation between the epistemological principles of the dialogical discourse approach (DDA) and the comparative discourse analysis, of French origin and studied by members of CLESTHIA-CEDISCOR laboratory. In Brazil, the research group Diálogo (CNPq/USP) has sought to bring together knowledge of both aforementioned approaches, as carried out in this study.

Keywords: Comparative discourse analysis; dialogical discourse approach; ENEM; Baccalauréat.

\section{Notas}

1 Ainda que não se tratasse de um documento normativo, os PCNs constituíram um material de muita repercussão no nosso país, cujas orientações buscavam auxiliar os educadores a atingir os objetivos previstos na nova Lei de Diretrizes e Bases da Educação Nacional (LDBEN, 1996).

2 O laboratório CLESTHIA surgiu em 2014 "da fusão de três equipes de linguística da Universidade de Paris 3", dentre elas o CEDISCOR (Centre de recherches sur les discours ordinaires et spécialisés). Cf. http://www.univ-paris3.fr/clesthia-langage-systemes-discours-ea-7345-98241.kjsp Acesso em: 29/05/2021.

3 Baccalauréat: "Grau universitário frances (criado em 1808) conferido após exames que finalizam os estudos secundários" [traduçao nossa]. Cf. Dicionário eletrônico Le Grand Robert de la Langue Française (2005). As traduções dos trechos citados são de autoria de D. N. Sardá.

4 No original: "Dans les textes officiels des années 2000-2010, la dissertation est clairement liée à l'argumentation".

5 A dissertação de filosofia, por exemplo, é uma prova clássica na cultura francesa, pois essa é a disciplina que tradicionalmente inaugura a sessão de provas desse exame a cada ano.

6 Os dois gêneros que trabalham a argumentação são o comentário de texto e a dissertação. Cf. programa https://www.education.gouv.fr/cid55410/ mene1104134a.html Uma reforma do ensino está em curso no ano escolar de 2020-2021; dado o caráter demasiado recente dessa reforma, trabalharemos, neste artigo, com a perspectiva anterior.

7 No original: "La dissertation consiste à conduire une réflexion personnelle et argumentée à partir d'une problématique littéraire issue du programme de français. Pour développer son argumentation, le candidat s'appuie sur les textes dont il dispose, sur les 'objets d'étude' de la classe de première ainsi que sur ses lectures et sa culture personnelle".

8 Mencionemos, por exemplo, o PCN do Ensino Médio (BRASIL, 2000b), na área de Linguagens, Códigos e suas Tecnologias, que cita, no decorrer do material e na sua bibliografia, a obra Marxismo e Filosofia da Linguagem (na versão da editora Hucitec, de 1998); assim como o PCN+ (BRASIL, 2006), que faz referência à obra Estética da Criação Verbal (publicada pela editora Martins Fontes em 1992). 
9 É importante destacarmos que as edições das obras dos autores do Círculo (principalmente de Mikhail Bakhtin e Valentin Volóchinov) em português, disponíveis na época da elaboração dos PCNs, eram traduções indiretas de outras línguas, como o francês e o inglês. Consequentemente, a autoria dos textos, a sua cronologia bem como outras informações veiculadas à época (que hoje já nos foram esclarecidas pelas traduções diretas e por pesquisas dos tradutores) eram equivocadas, o que não desqualifica a importância daquelas edições para os nossos estudos e, também, para a educação brasileira em geral.

10 A redação do ENEM tem um valor total máximo de mil pontos, dividido em cinco competências com os seus respectivos valores e critérios. Eles estão disponíveis na Cartilha do Participante do ENEM contida nas referências deste trabalho (BRASIL, 2020).

11 No original: "La voie générale se transforme : Pour les élèves de terminale de 2020, elle comprend encore trois séries ( $\mathrm{ES}, \mathrm{L}$ et $\mathrm{S}$ ) qui mènent au baccalauréat général. Pour les élèves qui passent le baccalauréat général en 2021, les séries ont fait place à des spécialités, choisies en fin de seconde. La voie générale conduit à la poursuite d'études supérieures principalement en université, classe préparatoires aux grandes écoles ou en écoles spécialisées".

12 Disponível em: https:/etudiant.lefigaro.fr/orientation/actus-et-conseils/detail/article/les-bacheliers-ne-veulent-plus-disserter-5804/ Acesso em: 24/05/2021.

13 No original: "Ils sont entre 10 et $15 \%$ à choisir la dissertation, à laquelle ils préfèrent le commentaire et l' 'écriture d'invention"'.

14 No original: "une réflexion personnelle et argumentée à partir d'une problématique littéraire issue du programme de français."

15 No original: "Dans les textes officiels des années 2000-2010, la dissertation est clairement liée à l'argumentation, comme le montre notamment la définition actuelle de l'épreuve à l'EAF (Épreuves anticipées de français ; $B O$ spécial $\mathrm{n} \square 7 \mathrm{du} 6$ octobre 2011), qui est restée strictement identique depuis 2001 [...] Cette définition fait écho à de nombreux passages des programmes : les lycéens 'doivent être capables, à partir de leurs lectures, de formuler un jugement personnel argumenté, notamment dans un commentaire ou une dissertation'; 'les exercices d'analyse, de commentaire et de dissertation concourent' à 'la maîtrise de l'expression écrite autonome' dans 'les écrits d'argumentation et de délibération' (programme de première, $B O \mathrm{n}^{\circ} 28 \mathrm{du} 12$ juillet 2001) ; et dans le programme de seconde comme dans celui de première, commentaire et dissertation sont les deux seuls exercices cités dans la rubrique de 'l'écriture d'argumentation' ( $B O$ spécial 9 du 30 septembre 2010)".

16 Empregamos, aqui, o termo "tipo", pois é o que mais aparece nos textos brasileiros.

17 No original: "D'une certaine manière, la dissertation littéraire résiste à être décrite simplement comme un genre argumentatif, et la réduire à sa composante argumentative, loin d'être une aide à sa production, est sans doute un obstacle à la fois méthodologique et cognitif, tant elle reste aussi un genre évaluatif, dont la dimension thématique (celle des contenus) est centrale."

17 No original: "dans le domaine du FL1, les genres ont été abordés dans le cadre des recherches sur l'interactionnisme socio-discursif (Bronckart et al. 1985, Bronckart 1996) [...]”.

19 No original: "1 - Mouvement littéraire et culturel [...] 2 - La poésie [...] 3 - Le théâtre: texte et représentation [...] 4 - Convaincre, persuader et délibérer: les formes et les fonctions de l'essai, du dialogue et de l'apologue [...] 5 - Le biographique [...]".

20 No original: "En classe de première, on étudie en tant que tel un mouvement littéraire et culturel français et européen du XVIème au XVIIIème siècle ; d'autres mouvements le sont en liaison avec les autres objets d'étude. On construit des relations de comparaison et de chronologie entre les mouvements étudiés enseconde et en première."

21 https://www.education.gouv.fr/bo/19/Hebdo14/ MENE1908240N.htm?cid_bo=140520 Acesso em: 29/05/2021.

22 No original: "Pensez-vous que la poésie nous éloigne du réel ou au contraire nous aide à mieux le percevoir ? Vous répondez à cette question en un développement argumenté, appuyé sur les textes du corpus, sur ceux que vous avez étudés en classe et sur vos lectures personnelles. Corpus : Victor Hugo, J'aime l'araignée, Les Contemplations, 1856.; Charles Baudelaire, Les Fenêtres, Le Spleen de Paris, 1869; Francis Ponge, Le Pain, Le Parti pris des choses, 1942".

23 Os sublinhados e os itálicos constam do original. Assinalamos em negrito as passagens por nós analisadas.

24 Barra colocada pela professora, para marcar a ausência de pontuação, provavelmente.

25 Optamos por não traduzir os títulos das obras.

26 Correção da professora na margem do texto: "Eluard". 
27 No original: "Les plus désespérés sont les chants les plus beaux, / Et j'en sais d'immortels qui sont de purs sanglots, écrit Alfred Musset dans sa Nuit de mai. Commentez et discutez cette affirmation en vous appuyant sur les textes du corpus et sur les poèmes que vous connaissez. Corpus: Alfred de Musset, La Nuit de mai, Les Nuits, 1835; Théophile Gautier, Le Pin des Landes, Espagna, 1845 ; Victor Hugo, Demain dès l'aube, Les Contemplations, 1856 ; Paul Éluard, Notre Vie, Le Temps déborde, 1947”.

28 No original: "Jean Cocteau définit ainsi le rôle de la poésie : Elle dévoille, dans toute la force $d u$ terme. Elle montre nues, sous une lumière qui secoue la torpeur, les choses surprenantes qui nous environnent et que nos sens enregistrraient machinalement. Dans quelle mesure partagez-vous cette conception de la poésie ? Vous répondez à cette question en un développement argumenté, appuyé sur les textes du corpus, sur ceux que vous avez étudiés en classe et sur vos lectures personnelles. Corpus : Jean Cocteau, Le Secret professionnel, 1926 ; Francis Ponge, Le Parti pris des choses, 1942, Jacques Réda, Retour au calme, 1989.”

29 No original: "Dans quelle mesure l'expression des idées politiques a-t-elle sa place, selon vous, dans le genre romanesque ? Vous répondrez à cette question en un développement ordonné qui prendra appui sur les textes du corpus, sur ceux que vous avez étudiés en classe et sur vos lectures personnelles. Corpus : Victor Hugo, L'Homme qui rit, 1869 ; Jules Vallès, Le Bachelier, 1881 ; Émile Zola, Germinal, 1885.”

30 No original: "V - RELATIONS AVEC LES AUTRES DISCIPLINES

Discipline carrefour, le français développe les compétences indispensables dans toutes les disciplines. Des relations plus précises seront établies et indiquées comme telles aux élèves avec les disciplines suivantes :

- les arts, notamment pour l'étude des genres et registres, de l'histoire culturelle et l'analyse de l'image ;

- les langues anciennes, pour l'étude des genres et registres, de l'histoire littéraire et culturelle, du lexique ;

- les langues vivantes, en particulier dans l'approche des mouvements culturels européens ; - l'histoire, y compris l'histoire des sciences, pour la construction de problématiques d'histoire culturelle ;

- la philosophie, que les élèves aborderont en terminale, par la réflexion sur les registres, sur l'histoire culturelle et sur la langue, et par la formation au commentaire de texte et la dissertation. Cette liste n'est pas limitative ; chaque professeur l'enrichira en fonction du projet pédagogique de la classe et de l'établissement".

31 No original: "Dans quelle mesure la mise en scène d'une œuvre théâtrale en constitue à sa manière une interprétation? Vous répondrez à cette question en un développement argumenté appuyé sur les textes du corpus, sur les pièces que vous avez étudiées en classe et sur vos lectures personnelles. Corpus : Molière, Les Précieuses ridicules, 1659 ; Molière, L'École des femmes, 1662, Beaumarchais, Le Mariage de Figaro, 1782".

32 No original: "outil d'analyse, à la fois théorique et méthodologique, de l'évolution des contenus disciplinaires et des pratiques enseignantes”.

\section{Referências}

BARBOSA, V. F. Uma voz apagada? Análise da atividade de revisão de textos acadêmicos sob as perspectivas bakhtiniana e ergológica. Tese (Doutorado em Linguística) - Pontifícia Universidade Católica do Rio Grande do Sul, Porto Alegre, 2017.

BEYER, C. Les candidats au bac ne veulent plus disserter. Le Figaro. 11 jun. 2014. Disponível em: <https://etudiant.lefigaro.fr/orientation/actus-et-conseils/detail/article/lesbacheliers-ne-veulent-plus-disserter-5804/. Acesso em: 24 maio 2021.

BAKHTIN, M. Teoria do Romance I: A estilística. Tradução de Paulo Bezerra. São Paulo: Editora 34, 2015.

BAKHTIN, M. Os gêneros do discurso (19521953). Tradução de Paulo Bezerra. São Paulo: Editora 34, 2016.

BRASIL, Parâmetros Curriculares Nacionais (PCN). Parte I: bases legais. Brasília, MEC, 2000a.

BRASIL, Parâmetros Curriculares Nacionais (PCN). Parte II: Linguagens, Códigos e suas Tecnologias. Brasília: MEC, 2000b.

BRASIL, Orientações Educacionais Complementares aos Parâmetros Curriculares $\mathrm{Na}$ - 
cionais (PCN+). Linguagens, Códigos e suas Tecnologias. Brasília: MEC, 2006.

BRASIL. Base Nacional Comum Curricular (BNCC). Educação é a Base. Brasília, MEC/ CONSED/UNDIME, 2017.

BRASIL. Instituto Nacional de Estudos e Pesquisas Educacionais Anísio Teixeira (Inep). A redação no Enem 2020: cartilha do participante. Brasília, DF: INEP, 2020.

CLAUDEL, C.; LAURENS, V. Le genre discursif comme objet d'enseignement en didactique du français. SHS Web of Conferences $/ 5^{\mathrm{e}}$ Congrès Mondial de Linguistique Française, vol. 27, 07005, 2016.

DIAS-CHIARUTTINI, A. Le débat interprétatif : un genre disciplinaire. Apports et limites d'un " outil » d'analyse de l'évolution d'une discipline scolaire. Linguarum Arena, vol. 5, 2014, p. 9-20.

DICIONÁRIO ELETRÔNICO LE GRAND ROBERT DE LA LANGUE FRANÇAISE. Paris: Le Robert, 2005.

DENIZOT, N. La dissertation: un genre scolaire argumentatif? Perspective historique. Pratiques, nํㅜㄴ 157-158, 2013, p. 165-176.

FRANCE, MINISTÈRE DE L'ÉDUCATION NATIONALE, DE LA JEUNESSE ET DES SPORTS. Le lycée, 2021. Disponível em: <https://www.education.gouv.fr/lelycee-41642>. Acesso em: 23 maio 2021.

FRANCE, MINISTÈRE DE L'ÉDUCATION NATIONALE, DE LA JEUNESSE ET DES SPORTS. Programme de l'enseignement commun de français en classe de seconde générale et technologiqueet en classe de première des séries générales et programme de l'enseignement de littérature en clas-se de première littéraire. Bulletin officiel spécial $n^{\circ} 3$ du 17 mars 2011. Disponível em: $<$ https://www.education.gouv.fr/cid55410/mene1104134a.html>. Acesso em: 29 maio 2021.

FRANCE, MINISTÈRE DE L'ÉDUCATION NATIONALE, DE LA JEUNESSE ET DES SPORTS. Programme de l'enseignement commun de français en classe de seconde générale et technologiqueet en classe de première des séries générales et programme de l'enseignement de littérature en clas-se de première littéraire. Bulletin officiel spécial $n^{\circ} 9$ du 30 septembre 2010, 2010. Disponível em: <https://www.education.gouv.fr/bo/2010/ special09/mene1019676a.html>. Acesso em: 29 maio 2021.

FRANCE, MINISTÈRE DE L'ÉDUCATION NATIONALE, DE LA JEUNESSE ET DES SPORTS, Baccalauréat. Épreuve écrite de français. Bulletin officiel du 04 décembre 2006. Disponível em: <https://www.education.gouv.fr/bo/2006/46/MENE0602948N. htm>. Acesso em: 24 maio 2021.

FRANCE, MINISTÈRE DE L'ÉDUCATION NATIONALE, DE LA JEUNESSE ET DES SPORTS. Programme de l'enseignement commun de français en classe de seconde générale et technologiqueet en classe de première des séries générales et programme de l'enseignement de littérature en classe de première littéraire. Bulletin Officiel du ministère de l'Éducation Nationale et du ministère de la Recherche $\mathrm{n}^{\circ} 28$ du 12 juillet 2001, 2001. Disponível em: <https://www. education.gouv.fr/bo/2001/28/encartc.htm>. Acesso em: 29 maio 2021.

GRILLO, S. V. de C. A linguística em manuais brasileiro e soviético, Alfa, vol. 64, e11752, 2020, p. 1-30.

LIMA, F. F. P. de A. \& BACELAR, A. P. de S. Das práticas sociais ao conteúdo temático: interfaces da intervenção no gênero redação do Enem. Linguagem \& Ensino, Pelotas, v. 22 , n. 1, p. 87-101, jan./mar. 2019.

MEDVIÉDEV, P. N. O método formal nos estudos literários: introdução crítica a uma poética sociológica [1928]. Trad. Sheila Grillo e Ekaterina Américo. São Paulo: Contexto, 2012.

OLIVEIRA, F. C. C. de. Um estudo sobre a caracterização do gênero redação do Enem. Tese de doutorado. Universidade Federal do Ceará, 2016, 167 f. 
SARDÁ, D. N. A análise de discursos comparativa no Brasil: uma reflexão a partir da noção de categoria. Bakhtiniana, São Paulo, vol. 16, n. 2, p. 153-177, abr./jun. 2021.

. A divulgação da filosofia nas revistas Philosophie Magazine e Filosofia Ciência \& Vida. Cadernos de Estudos Linguísticos, Campinas, vol. 62, p. 1-15, e020020, 2020.

VOLÓCHINOV, V. Marxismo e Filosofia da Linguagem: problemas fundamentais do método sociológico na ciência da linguagem. Tradução de Sheila Grillo e Ekaterina Vólkova Américo. 2. ed. São Paulo: Editora $34,2018$. 